\title{
Articles
}

\section{CERTIFICATION AS A VIABLE QUALITY ASSURANCE MECHANISM IN TRANSITION ECONOMIES: EVIDENCE, THEORY, AND OPEN QUESTIONS}

\author{
Andreas Ortmann, Katarína Svítková*
}

\begin{abstract}
:
Traditionally, enforcement of consumer protection laws meant to provide quality assurance of goods and services was considered a responsibility of the state in its various guises. Unfortunately, enforcement is an expensive, and hence particularly problematic proposition in transition economies that have many competing demands on their very scarce resources. An alternative mode of enforcement is through reputation. Yet for reputation to be able to fulfill this disciplining role, a high degree of information flow, or transparency, is imperative. Transparency, of course, is not something that transition economies typically excel in. In this article we discuss a third form of enforcement that relies much less, or not at all, on the state, and that relies on the market only indirectly: Certification agencies force their members to reveal their (good) type through costly signals that can be "engineered" to induce a separating equilibrium. We discuss the viability of this system of enforcement in an environment (namely, fundraising) where state and market have failed to deliver a satisfying degree of quality assurance.
\end{abstract}

Keywords: experience goods, quality assurance, certification, self-regulation, enforcement, transition economies

JEL Classification: C72, D21

* Center for Economic Research and Graduate Education, Charles University and Economics Institute, Academy of Sciences of the Czech Republic, Politických věznů 7, CZ - 11121 Praha 1 (andreas.ortmann@cerge-ei.cz; aortmann@yahoo.com); School of Business Administration, The New Anglo-American College in Prague, Lázeňská 4, CZ - 11800 Praha 1 (katarina.svitkova @ cerge-ei.cz, katarina.svitkova@aac.edu)

We are grateful to Rene Bekkers, Andrew Reading, Buzz Schmidt, Burkhard Wilke, Martina Ziegerer, and Jos Zwartjes for lengthy conversations and discussions. We also thank participants at the ICFO annual meeting 2004 in Vienna for their willingness to share freely with us their insights on certification issues. None of them should be held responsible for any of the views expressed here (especially, if they concern the organizations they are affiliated with.) An earlier version of this article listed as co-author Adriana Krnacova. We thank her for her input at the early stages of this project. 


\section{Introduction}

Where there is a quality assurance problem, one often finds the belief that a law or regulation can, and ought to, take care of it (Muris, 2002; Roland and Verdier, 2003). Even under the best of circumstances, however, this belief is dubious. Third-party enforcement through the state is expensive and tends to be ineffective especially when the quality of goods and services is observable but not, or not easily, verifiable in court (Akerlof, 1970; Tirole, 1988) as is the case for the so-called experience goods. Every student, for example, knows when a professor takes his responsibilities lightly. Typically, however, a student will not be able to enforce good teaching, or dissertation supervision, in court. Things get worse when the quality is not even observable, or only at prohibitively high cost (Darby and Karni, 1973), as is the case for credence goods. How, for example, would one go about proving in court that one's donation to a nonprofit (e.g., for tsunami disaster relief efforts, or flood victims in the Czech Republic) was not used the way it was intended?

Drawing on the notion that consumers often have choices, and can vote with their feet if they are displeased with goods or services, economists have made the case for reputation as an effective disciplining device in many of the situations where third-party enforcement fails, or works poorly (e.g., Heal, 1976; Klein and Leffler, 1981; Ortmann 1999, 2001). Unfortunately, reputational enforcement can only work if supported by fairly strong information flows (Tullock, 1985; Frank, 1988, Chapter 3). So while the reputation of the local taxi enterprise (e.g., AAA) may be easy to ascertain, even for individual consumers, it is much more difficult to ascertain the quality of firms that provide educational, health, or other (social) services. What, then, can be done?

We propose that properly designed systems of certification have tremendous potential especially in situations where both the state and the market are likely to fail in their enforcement function. Throughout we use donative nonprofits (nonprofits which finance themselves significantly out of donations and hence have to raise funds from public or state entities) as a running example. We call the problem of asymmetric information in the context of donative nonprofits the fundraising problem. This problem is closely related to the problem of whether charities manage their funds wisely and efficiently, or the credibility problem (e.g., Gibelman and Gelman 2004; Ortmann and Schlesinger 2003). ${ }^{1}$ We note that most of our arguments apply also to commercial nonprofits, which rely to a significant extent on income from selling their products, and, more generally, even to for-profits that provide experience or credence goods. ${ }^{2}$

We choose donative nonprofits as our running example because our article is also meant to inform the discussion about a certification system for donative nonprofits in

1 Roughly speaking, the credibility problem is concerned with nonprofits' doing what they say they would, and whether they do so wisely and efficiently. Thus, all nonprofits face it whether they raise funds or not. In a sense, the credibility problem addresses the issue of whether nonprofits deliver the quid-pro-quo that is implied by their tax and regulatory breaks. The fundraising problem identifies the credibility problem with respect to a specific, and arguably particularly important source of revenue that tends to be most severely exposed to the asymmetric information problem.

2 Indeed, we find quality assurance systems in other industries, such as the well-know ISO system (Terlaak and King, 2006), or the accreditation systems for institutions of higher education (Sperling and Tucker, 2006/1997). 
the Czech Republic. The design will draw on the experiences of similar initiatives in Europe, Canada, and the USA. ${ }^{3}$

Theoretical reflection seems warranted since the extant systems display remarkable diversity. This diversity is, maybe, not surprising given that these systems evolved at different times and places, and that an optimal system for all these circumstances is unlikely to exist. There are also prominent examples of projects that faltered over the last few years. Given that significant sums are involved in the design and implementation of certification systems, theoretical reflection about such system seems, in fact, imperative.

The remainder of the paper is structured as follows: In Section 2 we describe U.S. attempts to solve the fundraising problem as well as some European success stories of certification solutions to the fundraising problem. We also pay attention to a failed attempt at such a solution - "we learn from failure, not from success!" (Stoker, 1897) after all. In Section 3 we sketch out the stylized facts, or commonalities, that emerge from our review. In Section 4 we examine what economic theory has to say about the stylized facts that we identified and about the fundraising problem, and where the extant theory is deficient. Section 5 concludes with a list of design and implementation issues.

\section{The Fundraising Problem: Some (Attempted) Solutions}

The nonprofit (also called the third, or civil) sector finances itself partially out of donations, contributions from citizens and grant-making agencies that may or may not be dedicated to a specific purpose. Typically, nonprofits solicit donations either through their own fundraising activities, or through specialized fundraising organizations. ${ }^{4}$ Fundraising brings up a number of interesting issues. For example: do those competing for funds honor truth in advertising, or do they dramatize their mission to increase the willingness of potential donors to give? What is an appropriate fundraising ratio anyway? That is, how much should it cost to raise a dollar or euro to fund some project that benefits the public? One percent? Ten percent? Twenty-five? Fifty? And, once funds have been raised, are they indeed spent for the purpose for which they were raised $?^{5}$

A prominent case that highlighted the fundraising and credibility problems was the Red Cross's Liberty Fund, set up as a special account to aid the victims of the September 11 attacks on the World Trade Center and the Pentagon. The Red Cross tried to divert some of these funds to upgrade its telecommunications system and to build up its blood reserves. While these activities may have been sensible things to do, they were not what

3 About a dozen working certification systems for donative nonprofits exist in Western European countries while none seems to exist in a transition country. It is our reading that throughout the nineties consumer protection was not a high priority. This may have been a response to more pressing demands on scarce enforcement resources, lack of effective consumer protection laws, and the fact that there was no strong demand for high quality and services to start with.

4 In rare occasions donations may come unsolicited.

5 This question addresses the wide-spread perception among donors that nonprofits, whether donative or commercial, are rather incompetent at spending money wisely and efficiently (e.g., Bradley, Jansen, and Silverman, 2003; Light, 2004, 2004a; Gibelman and Gelman, 2004). 
donors had in mind when they poured almost 1 billion dollar money into the fund. ${ }^{6}$ Less prominent but more pervasive (and harder to detect) are various forms of gift exchange, internal cross-subsidization, or mission drift (e.g., Ortmann and Squire, 2000).

Two facts suggest that these, or similar problems (e.g., "tunneling"), also afflict the nonprofit sector in the Czech Republic. Of the organizations comprising the Czech nonprofit sector, $88 \%$ are associations with no legal requirements mandating their accountability or disclosure of information. More closely followed organizations, such as foundations, foundation funds, and public benefit organizations comprise only $3.5 \%$ of the sector (Brhlíková, 2004). Nevertheless, even the disclosure of legally required information is lacking: in 2002, for example, only $32.9 \%$ of foundations and foundation funds supplied their annual reports to their respective courts as required by law (CVNS, 2004), a dismal record that is bound to induce lack of accountability and transparency.

Examples like the Red Cross's Liberty Fund, or the apparent lack of understanding of the importance of accountability and transparency displayed by the reporting behavior of Czech foundations or foundation funds, are likely to generate negative reputational spillover effects which can dramatically affect the trustworthiness, and ultimately the viability, of the third sector as a whole (Ortmann and Schlesinger, 2003; Gibelman and Gelman, 2004; Light, 2004, 2004a; Panel on the Nonprofit Sector, 2005; Senate Finance Committee staff, $2004^{7}$ ). What can be done? And what has been done elsewhere?

\section{2.a The U.S. solution(s)}

\section{2.a.1 IRS form 990, GuideStar, and related services}

Not surprisingly, given the prominent and relatively long-lasting role the third sector has played there, the USA has dealt with the fundraising problem for decades (e.g., Ortmann and Schlesinger, 2003, pp. 82 - 85; see also Stamler, 2004 a, b). Guided by a belief in the efficacy of laws and regulations, it tried to solve the fundraising problem using third-party enforcement. Specifically, the Internal Revenue Service (IRS), in conjunction with the General Attorney offices of the states, was charged with enforcing the non-distribution and reasonable compensation constraints, together with other regulations pertaining to nonprofits. Thus, a typical nonprofit organization in the USA with revenues above $\$ 25,000$ is legally required to fill out IRS Form 990 which requires nonprofits to divulge to the public information such as revenues, assets and expendi-

6 Light (2004 a, p. 1) argues that "the controversies surrounding the disbursement of the September 11 relief funds and subsequent nationally-visible scandals ... appear to have left a durable imprint that has yet to fade." Light (2004) backs up this statement with numerous survey data.

7 In response to the controversies surrounding the disbursement of the September 11 relief funds, etc., the Finance Committee of the Senate of the U.S.A. issued in summer 2004 the White Paper on various changes it might consider as a means to reduce abuse and fraud in the nonprofit sector and invited the Independent Sector (IS, www.independentsector.org) to comment on that draft. The IS, jolted into action by the White Paper, convened the Panel on the Nonprofit Sector (www.nonpro fitpanel. org) in a clear attempt to influence the outcome of the Finance Committee's deliberations. Nunez (2001) suggests in which direction this influence went; more on the issue of self-regulation below. 
tures for program activities, administration and fundraising, as well as information on board members, directors, and key employees, including their salaries. ${ }^{8}$

Several shortcomings of this solution have arisen over time: because the IRS simply did not have the resources, the overwhelming number of forms received were never used. This fact, in turn, reduced nonprofits' incentive to report properly and further decreased the quality of reports, which was already low because of high complexity and bad guidance (Froelich, Knoepfle, and Pollak, 2000, pp. 245 - 6; Senate Finance Committee staff, 2004, pp. 8 -9, pp. 18 - 19).

In an attempt to improve the accountability and transparency of the nonprofit sector, new legislation in 1999 and its interpretations required many organizations in the sector to make their Form 990 easily accessible. Internet-based services, such as GuideStar (www.guidestar.org), the National Center for Charitable Statistics (nccsdataweb.urban.org), or the cyber-accountability network (www.cyb-acc.org), have used those opportunities to provide guidance on how to fill out Form 990 and change nonprofits' incentives to report properly. ${ }^{9}$

GuideStar in particular is a tremendous success story by some measures. For one it has become the public disclosure vehicle of IRS data. Founded in 1994, it currently maintains database records for more than one million U.S. organizations and has extracted from the annual filings with the IRS extensive financial and descriptive records time series for the 300,000 largest nonprofits. Until recently, GuideStar's basic services were free to its more than 250,000 registered users, the majority of which are nonprofits. In an attempt to wean itself off donations ${ }^{10}$, Guidestar then decided to charge a monthly rate of $\$ 30$ for its basic services (such as accessing 990 forms) and about twice that for more advanced services such as "Analyst Reports" (including peer group comparisons) or "Compensation Reports".

GuideStar also supplements the IRS data with voluntary answers to its own questionnaire; by ratcheting up the scope of the questionnaire GuideStar could, and apparently intends to (although we have heard differing opinions on this issue), increasingly take on characteristics of a certification agency. ${ }^{11}$ Moreover, GuideStar, through GuideStar International, has started similar projects abroad: a U.K. branch was launched in 2004 (with Treasury grant of almost $\$ 5$ million as starter help), pilots are in the works in Germany, Hungary, India, and South Africa. All four prospective members of GuideStar International are scheduled to launch their websites by the end of 2006. Because in most countries GuideStar will not be able to work with a ready-made set of data similar to those provided by IRS Form 990, it will have to devise a system of

8 The minimum revenue cut-off point means that about $70 \%$ of nonprofits do not have to fill out Form 990.

9 www.cremn.org/npresources/truthtips.pdf

10 Fees covered about one third of GuideStar's $\$ 6$ million budget when it introduced its new pricing scheme. GuideStar had previously declared that it was trying to cover at least about two thirds out of fees.

11 It would be interesting to assess empirically how those that supplied additional information to GuideStar have fared in terms of their revenues relative to those that did not. Our conjecture is that it has not made a difference so far because the additional questions are too vague and can be answered falsely with impunity. 
voluntary submission of data. It will be interesting to see what kind of system of carrots and sticks will be devised to solve the problem.

The key problem with the GuideStar model is its exclusive reliance on information provided by the organizations themselves, leaving significant leeway for those that try to bend the rules. While it is likely to lead to increased transparency and accountability of the sector through increased accessibility and quality of the information reported in Form 990, it is for the time being unlikely to allow consumers to really sort out the good guys from the bad guys.

\section{2.a.2 U.S. certification systems}

Concerns about the efficacy of IRS enforcement motivated several nonprofits to start certification programs, e.g., Better Business Bureau (BBB) in 2003, the Maryland Association for Nonprofit Organizations (www.marylandnonprofits.org, from here on Maryland Nonprofits) in 1997. Here we briefly introduce the latter one, a certification program that checks the quality of nonprofits against Standards for Excellence. ${ }^{12}$ If the organization passes the certification check it is awarded the Standards for Excellence seal. In light of the fact that the program is now in the process of being implemented in other states ${ }^{13}$, it is considered a success in high places (e.g., Senate Finance Committee, 2004, p. 18), despite a relatively low and slowly increasing participation rate - about five percent - of organizations in Maryland.

There are two major differences between the certification provided by Maryland Nonprofits and that provided by non-profit certification agencies in Europe (discussed in the following section): Maryland Nonprofits aspire to ultimately award the certificate to all potential candidates, leading to a conflict of interest since Maryland Nonprofits also tries to fill the role of enabler towards that goals; and, on-site checks may occur but do not have to, making it more likely that bad types do not get recognized early enough.

Interestingly, a well-established certification agency - the ECFA (Evangelical Council for Financial Accountability, www.ecfa.org) which resembles the way the European certification agencies described below operate - has provided certification in the U.S.A. for more than 25 years. It is puzzling that there were no earlier attempts in the U.S.A. to start secular certification programs.

12 The Standards consist of guiding principles, such as honesty, integrity, fairness, respect, trust, compassion, and responsibility applied to eight areas of concern (e.g., Mission and Program, Governing Body, etc.) further developed in 55 specific standards, www.standardsforexcellencei nstitute.org.

13 In 2005, Maryland Nonprofits established the Standards for Excellence Institute that coordinates implementation of the program in other states (see www.standardsforexcellenceinstitute.org). As of Fall 2006, the program operates in more than a dozen states, but it is expected to be launched in twice as many in the near future. 


\section{2.b Seemingly successful European solutions: Examples from Germany, the Netherlands, Switzerland, and Austria}

Contrary to the U.S., third sector certification systems have a long tradition in several European countries (e.g., Switzerland, about 70 years, Norway and Sweden, about 60 years, France, 15 years, Germany and the Netherlands, about 10 years). Guet (2002), in close cooperation with the International Committee of Fundraising Organizations (ICFO), has described eight such systems within Europe (and two Christian monitoring agencies, in the USA and in Canada). Due to space constraints we focus on five of them. ${ }^{14}$

While there are many differences in the operation and funding of the certification agencies, two polar models emerge. One is the model pursued by the Dutch and German certification agencies, Central Bureau Fondsenwerving (CBF) and Deutsches Zentralinstitut für soziale Fragen (DZI), respectively. The other is pursued by the Austrian certification agency. The Swiss model is a hybrid of the two polar cases, albeit arguably closer to the Dutch-German model, particularly after the 2001 organizational change induced by the credibility problem that the previous organizational form brought about. At first glance, the organizational difference between the Dutch and German model on the one hand and the Austrian on the other is the decision to conduct the detailed evaluation of participant organizations in-house (the former) or to have it done by outside examiners ("Wirtschaftsprüfer", the latter).

All three certification agencies, DZI, CBF and ZEWO, have reached a general level of acceptance (about 30 percent name recognition in the total population, with the percentage being higher in that part of the population that indeed gives; see Bekkers, 2003), and with the reputation of the ZEWO seal so strong that some cantons do only approve collections by organizations which have the ZEWO seal of approval, while other cantons do ask the opinion of ZEWO before allowing a collection (Guet, 2002, p. 27). Along similar lines, in Germany the Federal Ministry on Economic Cooperation and Development and the Foreign Office have simplified their application procedures for those charities which have been awarded the DZI seal of approval (Wilke, 2003).

All considered systems focus on national and supra-regional fundraising institutions, they provide to various degrees information about entities that have not been certified (yet); they also pursue, to varying degrees, other activities (e.g., publish almanac, gather information about the sector). They approve the seal for a fixed period of time (DZI, yearly; CBF and ZEWO, every 5 years), with an intense initial screening process at the beginning. They all require more information than just the financial statements, not only for the sake of the information itself but also to observe the applicant's willingness to divulge those bits of information. If a charity is less than forthcoming with the required information, it is taken as a signal of its lack of

14 Our discussion draws on Bekkers (2003), Guet (2002), information generously supplied by the organizations, as well as lengthy interviews Ortmann and Krnacova had with the chief executive officers of CBF and the DZI, a one-hour telephone conversation that AO had with the chief executive of ZEWO, numerous conversations that the present authors had at the ICFO meeting in Vienna in May 2004 and the CERGE-EI-Transparency International workshop on certification systems in Prague in April 2005. 
trustworthiness. These agencies believe that it is their job to assess trustworthiness but not to induce it; a strategy that is in marked contrast to that of Maryland Nonprofits.

All three institutions charge for certification, the fee depends on the costs of the evaluation or on the volume of fundraising income. ${ }^{15}$ It is important to understand that these out-of-pocket expenses are, however, only part of the total costs of acquiring, and maintaining, the seal of approval. Since the information required goes significantly beyond the financial statements, there is substantial cost connected to the provision of that information. Exactly what these costs are, we have not been able to discern; they seem to vary widely (from less than a week to several weeks of manpower).

Interestingly, CBF (about 40 percent) and DZI (about 30 percent) are not fully financed from fees paid by the monitored charities. ${ }^{16}$ In contrast, all other certification agencies (ZEWO including) discussed in Guet (2002) are (almost) completely self-financed from fees paid by the evaluated charities or from contributions. That said, the depth of investigation and therefore the detection probability of "bad apples" differs dramatically across CBF and DZI on the one hand and other organizations on the other: The depth of investigation is a, if not the, key cost-component of certification activities, and any assessment of a certification procedure has to trade off these costs with the welfare benefits of an increased detection probability. In addition, less than full reliance on fees is likely to increase an agency's independence from its customers.

The Austrian model differs radically from that of its Dutch and German counterparts. Specifically, the Austrian Institute for Fundraising (Österreichische Institut für Spendenwesen - ÖIS; founded in 1996) defines as its major function, similar to DZI, provision of information about the sector. The ÖIS is a division of the Austrian Foundation for Development Aid Research (Österreichische Forschungsstiftung für Entwicklungshilfe, ÖFSE). Although the ÖIS was involved in the development of the standards for the seal of approval, the seal of approval itself (awarded since November 2001) is administered by the Chamber of Accountants (Kammer der Wirtschaftstreuhaender). ${ }^{17}$ In effect, the whole certification operation at the Kammer exists of one person who spends, supported by a secretary, part of his/her time on coordinating the activities connected with this job. How does he/she do it? By reliance on external accountants that are paid in full by the applicants.

15 For example, the initial fees charged by DZI and CBF in 2005 were $€ 1,500$ and $€ 3,630$ respectively; subsequent evaluations (each year) are $€ 500-7,000$ and $€ 250-5,000$, respectively, depending on the size of the organization that is evaluated. ZEWO charged, in 2005, an initial fee of $€ 2,260-4,500$, annual fees of $€ 320-7,000$ (with the average being about $€ 600$ ), and recertification fees amounting to $€ 1,200-2,260$. The annual fees are computed as 0.25 per mill of revenues.

16 To be more precise: For 2005, DZI had a budget of $€ 1,050,000$ from which about $€ 430,000$ was its own income in the form of certification fees $(€ 300,000)$, library/publishing $(€ 95,000)$, etc. DZI's donor advice and seal-of-approval departments (roughly comparable to CBF as a whole) had a budget of $€ 670,000$, with $€ 330,000$ being its own income and $€ 340,000$ being subsidies from the federal government.

17 It is our understanding that this was the result of a compromise of sorts. ÖFSE was originally interested in building a DZI-like organization but could not get support from partners that later signed a three-year cooperation agreement that was implemented by the Kammer of Wirtschaftstreuhänder ("accountants"). 
The obvious advantage of this solution is the ability to rather quickly expand the number of certified firms. In the Austrian case, this means that almost 50 firms were certified during 2001, while during 2002 almost 100 firms $^{18}$ (including most of the initial almost 50) made the grade - out of 600 organizations that qualify in principle.

The obvious disadvantage of the Austrian solution is the problem of quality assurance and comparability of the interpretation of the standards. The standards are by their very nature "soft" and open to subjective interpretation. As the reliance on external accountants increases, standards are more likely to be interpreted less uniformly. The incentives of external accountants may be very different from those of in-house evaluators.

The theoretical problem is to what extent the Austrian solution might increase the probability of an undeserving nonprofit being awarded the certificate (and possibly causing reputational spillover effects). The devil is clearly in the details here but the trade-off seems to warrant more investigation. On the basis of its relatively short track record, the Austrian model seems viable but it is, perhaps, too early to issue a final verdict. Hence the title of this section.

\section{2.c Some failures worth keeping in mind: Examples from Europe}

While there are a number of success stories, there are also a couple of interesting failures; we describe one of them: In 1996 the English Accrediting Bureau for Fundraising Organizations (ABFO), an initiative supported by the well-established Consumers' Association, developed standards for fundraising organizations and ran trials with 5 organizations that volunteered. An evaluation in 1997 claimed that the trials were successful and the standards effective: the fundraising organizations involved in the trials were reported as having seen accreditation as a "useful, positive health check". Yet almost three years later, only two organizations were accredited. This meager progress was attributed to two main obstacles: "the basic resistance of the entire charity sector to external scrutiny" and "the lack of an effective lobby, which believes fervently that charities should be susceptible to scrutiny, and in particular that fundraising charities should be accredited." That effective body could, and probably should have been, the Charity Commission, which never adopted the concept of certification, even though it now seems to accept the GuideStar U.K. initiative, and seems to have been pushed into reforming itself through this new threat. ${ }^{19}$ The support of the Consumers' Association ultimately was not sufficient to carry ABFO through.

It is difficult to assess what actually led to the non-acceptance of a proposition that in other countries thrived. The evidence seen and discussed suggests that the failure to bring key players from the sector on board, for whatever reason it was, seems to have been the kiss of death (at least for now) of the English patient.

18 Interestingly, these firms command about 25 percent of the funds that are raised by the 500 organizations that are not yet certified. To what extent this reflects some sort of selection bias, or to what extent it reflects already a pay-off of the increased trustworthiness that the seal bestows is an open question.

19 See the April 1, 2004 announcement of its own online database launch of charity accounts and governing documents. 


\section{2.d Self-regulation}

Self-regulation represents yet another form of quality assurance, it is a voluntary acceptance of a code of conduct by members of a club. This code is usually created by an 'umbrella' organization, an organization providing services to institutions in certain field, or by a group of organizations with a similar purpose. Signing of the code means the organization is voluntarily willing to follow the rules and regulations listed there. Examples of this type of regulation abound (Wyatt, 2004); in the fundraising industry we can mention the German Deutsche Spendenrat (www.spendenrat.de) or the Czech Donors' Forum (www.donorsforum.cz) as examples of such institutions.

The main problem with codes of conduct is their reliance on self-reporting, i.e. the organizations are trusted to follow the regulations without any checks leaving significant space for abuses and provision of false information. We believe that the rather meager success that both mentioned organizations had is a result of the structural problems of such self-regulated systems. ${ }^{20}$ Nunez (2001) provides an insightful model of self-regulation and shows that self-regulatory organizations typically have little incentive to monitor quality and to reduce fraud, at least without public parallel regulation. $^{21}$

Until 2001, ZEWO was more akin to a self-regulatory collective. As mentioned, the "credibility problem" that this organizational form brought about prompted a radical reorganization towards consumer protection significantly reducing the influence of the fundraising organizations, seemingly to the benefit of society at large. The trick is to find the right balance of independence and involvement, of reasonably disinterested investigation and informed standards.

\section{Discussion of Various Systems}

In this section we summarize the commonalities and main differences among the systems described above. We do so along two dimensions (see Table 1): first, internally or externally developed and imposed standards (where the label "external" captures the independence of the issuing agency from applicants), and second, self-reported data or data produced through "investigators". The categories chosen are ideal types; one almost never finds them in such purity. For example, certification investigators still rely to some extent on self-reported data. The key difference is that investigators can force applicants to divulge data that they otherwise might have chosen not to reveal, what significantly changes the nature of the information revelation game.

20 In essence, they are prone to violate one or more of three criteria for a good certification system identified by the the Institut für Ökologische Wirtschaftsforschung: independence of the issuing agency, objectivity of the criteria/the degree to which the criteria go beyond legal or regulatory requirements, and transparent development of the criteria/the thoroughness with which the evaluations are conducted.

21 In some respects, Nunez (2001) explains well the bargaining game that has taken place over the past years between the Senate Finance Committee in the U.S. and the nonprofit sector there. 
Table 1

\begin{tabular}{|l|l|l|l|}
\hline \multicolumn{2}{|c|}{} & \multicolumn{2}{c|}{ Standards set } \\
\cline { 3 - 4 } Information provision & Self-reported & $\begin{array}{l}\text { Internally } \\
\text { Codes of conduct } \\
\text { (Deutsche Spendenrat, } \\
\text { Donors Forum) }\end{array}$ & $\begin{array}{l}\text { IRS Form 990, } \\
\text { GuideStar }\end{array}$ \\
\hline & Investigated & Accreditation & $\begin{array}{l}\text { Certification systems, } \\
\text { ISO }\end{array}$ \\
\hline
\end{tabular}

A system based on self-reported data has one important advantage: it is cheap. But, the quality of self-reported data is likely to be inferior even in the best of circumstances (i.e., when the club understands the importance of truthful and complete reporting). A system based on self-reports also requires significant interest and knowledge of consumers (i.e., they read and understand the provided information), as well as sufficient information flows (i.e., consumers share their knowledge about firms they experienced). If these conditions (necessary but not sufficient) are not met, the system leaves significant room for abuse and misrepresentation (e.g., the problems with IRS Form 990 reporting described in Section 2.a).

A system based on data produced through "investigators" has corresponding pros and cons. The acquisition of data is likely to be more expensive - possibly significantly more expensive - but the quality of these data is likely to be higher. The question is whether these expenses are worth it. In Section 4 we discuss economic models of quality signaling which suggest that the answer depends: it hinges importantly on the costs it takes to detect "bad apples" (the detection probability) and the social welfare (the relevance of savings in transaction and information costs prompted by such a system).

As to our distinction of standards, our intuition as well as theoretical work in this area (Nunez, 2002) suggests that standards set internally are likely to be less binding than those set externally. Indeed, the rules imposed by the IRS, for example, are more binding than those imposed by codes of conduct that a club-like set of organizations might report. This further enforces the problem of inducing firms to participate in such systems, what is usually done either by using legal force or through convincing arguments about gains related. If the system is designed without the participation of key players in the target market, ${ }^{22}$ they may feel the rules are imposed on them (similar to legislation but without the enforcing powers) and resist participating. In the end such system fails, as seen in the English case.

The main advantage of a self-regulated system with its own standards is the involvement of the target organizations. Unfortunately, this may also be the major disadvantage, as the involvement may lead to an inability to overcome opportunistic and shortsighted behavior; lack of transparency and accountability are almost guaranteed in situations where tightly-knit groups of people interact.

22 All stakeholders' groups shall be involved: target organizations, donors, and government representatives. 
The optimal design of a quality assurance system must avoid the threats identified above; the evidence, that we have reviewed seems to suggest that independent investigators may be a key component of any promising solution. That said, while external standards are important, it is equally important to make sure that a critical mass of target organizations will buy into the basic idea, its design and implementation.

\section{The Economics of Certification}

\section{4.a Commonalities}

Even though, as we have documented, there are many variants of certification models, there are some interesting commonalities: First, candidates for a seal of approval voluntarily provide information that often goes well beyond the legal (accounting) requirements. How much more is arguably the key design and implementation parameter of a certification agency, for it is likely to limit its coverage. Closely related is the issue of how likely a certification agency is to catch a bad apple, which can spoil the reputation of the seal of approval (and the good apples). Second, candidates for a seal of approval not only send a signal, but send a costly signal, through out-of pocket expenses (e.g., the examination fee that they have to pay) as well as the costs it takes to collect the requested information ${ }^{23}$. Third, most of the systems that we considered above focus on organizations raising funds nationally, rather than locally. The national focus may result from the fact that the pay-offs from certification are higher on the national level (where building a reputation is probably much more expensive). Fourth, all current certification providers use essentially one disclosure rule: the seal of approval; they neither rank the organizations nor provide full disclosure of their findings. Indeed, very little additional information is made public, often the applicants are assured that the provided materials are confidential and will not be made public. Fifth, both CBF and DZI have managed to build their reputations quite quickly. Bekkers (2003), for example, reports that the recognition rate of the CBF seal of approval almost doubled over the two-year span from 2001 to 2003 and that the seal of approval was known by one third of the population at large in 2003, and by half of those who give. Intuition suggests that these recognition figures translate into higher giving to those that are certified, although direct evidence does not seem to exist. Indirect evidence exists in the form of the number of applications and the fact that firms that initially refused to sign on, often do later. Sixth, all certification providers are nonprofit, with CBF and DZI being funded significantly, albeit decreasingly, with state money in various guises. Public subsidies seem to be not unwarranted: certification agencies do provide a public service, and public funds prevent large fundraisers from getting too much influence on certifier's operation.

23 None of these costs of course matters substantially in the GuideStar model, so we expect systematically lower signaling and separating effects unless GuideStar adds more information gathering components into its data collection efforts. But any such attempt would increase the costs of doing business significantly. 


\section{4.b Why? What theory says ...}

Why would a company pay out-of-pocket and significant personnel expenses to be certified? Unless the company is irrational, it has to have the expectation that there will be a pay-off that makes the investment worthwhile.

It turns out that economists have thought about such mechanisms for a while. In the language of economics, the willingness to provide the requested information - at substantial out-of-pocket and personnel expense - is a costly signal of one's "type". The signal induces a "separating" equilibrium in which participating players reveal themselves as "good" types, while those not participating are revealed as "bad" types. ${ }^{24}$

So again, then, why would a company pay to be certified? The key to the answer lies in the demand shifts prompted by a successful separating equilibrium: the demand curve shifts out on the good types while it shifts in on the bad ones. The shift may be budget neutral (the total volume of giving remains the same), but it does not have to be. In fact, it seems that a nonprofit sector that is trusted will on average be able, ceteris paribus, to collect more funds that one whose reputation is shot (Bekkers, 2003).

Several rather technical papers have been written on the topic of certification (also referred to as intermediation). In the present context the following papers are of interest: Biglaiser (1993), Biglaiser and Friedman (1994), Lizzeri (1999), and Strausz (2005).

Biglaiser (1993) shows that an intermediary indeed has the potential to increase the welfare of society in situations with asymmetric information. He considers an ongoing market in which buyers buy and sellers sell one unit of an experience good. The good has either a high or low quality, which is given but unobservable. The intermediary increases the welfare of society by increasing the speed of transactions; he is able to do this because, as the only agent in the market, he buys more than one unit of the good, thus gains experience faster. The intermediary does not cheat, because the short term gains from selling low quality goods for a high price are outweighed by the 'infinitely' repeated profits if the intermediary stays in the market forever and maintains his reputation.

Shortcomings of the model were addressed in a follow-up paper by Biglaiser and Friedman (1994), where the authors analyse the role of an intermediary in situations where sellers choose quality of the goods they sell (moral hazard problem). They show that the intermediary again mitigates the problem and increases the welfare of society.

While the summarized models incorporate considerations of reputation and highlight the information advantage of the intermediary over other buyers, they neglect a feature that is of importance in the present context: the intermediary's decision process. Lizzeri (1999) focuses on this aspect using a different modeling approach: he analyses an asymmetric information problem in a one-shot game, in which the certifier provides the seller with an opportunity to reveal his quality if the seller chooses to do so. The certifier, through the choice of a disclosure rule (e.g., full disclosure, ranking, no

24 Interestingly, the good types do not have much of a choice. Once a critical mass of participants has been reached, consumers will view all firms that do not want to go through certification for one reason or another as not trustworthy. Hence, the trustworthy types have little choice but to get the seal (unless they are able to acquire a reputation of their own, which is unlikely to be a less costly strategy). 
disclosure) and a fee charged for certification, reveals some of the information to the buyers. Lizzeri assumes that the certifier can assess quality of sellers at no cost, and that buyers appreciate the quality revealed to them through the certificate.

While the model is rather abstract and assumes away several important considerations (e.g., reputation as an alternative information source, dishonest certifier, or imperfect detection of quality), it elucidates some important issues concerning certification: Assuming that the certifier chooses to fully disclose the information he obtains, Lizzeri identifies a separating equilibrium, in which 'good' sellers ask for certification, and 'bad' sellers do not. In contrast, in cases where the certifier chooses no disclosure, an undesired pooling equilibrium emerges, in which all sellers ask for certification and are awarded the certificate, and the certifier captures whole surplus, an optimal choice for a profit maximizing certifier. Lizzeri analyses also other extensions of the game: he examines, for example, a scenario with several certifiers, and shows that competition is able to shift power to consumers who end up completely informed.

Lizzeri (1999) highlights in a stark manner certain features of theoretical equilibria (some of which we seem to see implemented in real life), and helps us understand better the workings of these institutions. Particularly, he points out a significant threat: as we observe no disclosure being used by most agencies considered, we have to keep in mind that their temptation to shift to the pooling equilibrium (and certify most organizations in the market) is high. The outcome hangs on the profit-maximizing status of the agency; the nonprofitability of certification agencies discussed in Section 2.b. seems an optimal way to go (see Svítková and Ortmann, 2005).

According to Lizzeri it might seem optimal to build two competing agencies. Strausz (2005), however, suggests that honest certification "constitutes a natural monopoly" due to economies of scale resulting from the fact that certifier 'sells' reputation. ${ }^{25}$ Strausz models an infinitely repeated game (to allow for consideration of reputation) where sellers have an opportunity to bribe the certifier who, in return, lies about their quality. To give the certifier an incentive to be honest requires that future expected profits (if honest) are higher than the short-term gains from accepting a bribe. A monopolistic certifier has, naturally, the highest motivation to be honest.

\section{Discussion and Conclusion: Toward the Design and Implementation of Certification Systems in Transition Economies}

When it comes to consumer protection, we encounter sound but incomplete economic theory. We also encounter systems in other countries that work reasonably well. But reasonably well does not mean optimal. More importantly, these systems are in place in places where both legal enforcement and reputation have some bite.

In this article we have discussed a form of enforcement that relies much less, or not at all, on the state, and that relies on the market only indirectly: Certification agencies force their members to reveal their (good) type through costly signals that can be "engineered" to induce a separating equilibrium. We have discussed the viability of this

25 The fact that in all the countries discussed in Guet (2002) one, and only one, certification agency has managed to establish itself, is an interesting fact that suggests at first glance that there may be economies of scale (and scope) to be captured, at least for certain industries. 
system in environments where state and market have failed to deliver a satisfying degree of quality assurance, and have also discussed related systems of quality assurance.

Important questions - indeed questions that have to be answered by any real-life version of a certification system - are yet not answered in a completely satisfactory manner by economic theory. In concluding, we enumerate some of these questions to remind the reader of the complexity of the design and implementation problem. What exactly is the trade-off between the scope, and hence cost, of certification and the welfare benefits that can be captured through certification? How strong is the demand shift, for individual organizations as well as the whole sector, that trustworthiness buys? Does trustworthiness always pay off? To what extent should a certification agency be financed from public funds? How crucial is it that certification be done "in-house"? Who monitors the monitor? (Can reputation do the trick?) What is the critical mass of key members of targeted industries that one needs to get on board to launch a certification agency with a reasonable degree of confidence? Can self-regulation ever be a viable alternative to certification?

\section{References}

Akerlof, G. A. (1970), "The Market for Lemons." Quarterly Journal of Economics, 84, pp. 488-500.

Bekkers, R. (2003), "Trust, Accreditation, and Philanthropy in the Netherlands." Nonprofit and Voluntary Sector Quarterly, 32 (4), pp. 596-615.

Biglaiser, G. (1993), "Middlemen as Experts." RAND Journal of Economics, 24 (2), pp. 212-223.

Biglaiser, G., Friedman, J. W. (1994), "Middlemen as Guarantors of Quality". International Journal of Industrial Organization, 12, pp. 509-531.

Bradley, B., Jansen, P., Silverman, L. (2003), "The Nonprofit Sector's \$100 Billion Opportunity." Harvard Business Review, 81 (5), pp. 94-103.

Brhlíková, P. (2004), "The Nonprofit Sector in the Czech Republic." CERGE El Discussion Paper, No. 2004-128.

CVNS (2004), "Ekonomické výsledky nadačních subjektů v roce 2002 (Economic results of foundation-like organizations in 2002)." Brno : CVNS, August 2003.

Darby, M.R., Karni, E. (1973), "Free Competition and the Optimal Amount of Fraud." Journal of Law and Economics, 16, pp. 67-88.

Frank, R.H. (1988), Passions within Reason, The Strategic Role of the Emotions. New York : W.W. Norton \& Company, Inc.

Froelich, K.A., Knoepfle, T.W., Pollak, T.H. (2000), "Financial Measures in Nonprofit Organization Research: Comparing IRS 990 Return and Audited Financial Statement Data." Nonprofit and Voluntary Sector Quarterly, 29 (2), pp. 232-254.

Gibelman, M., Gelman, S.R. (2004), "A Loss of Credibility: Patterns of Wrongdoing Among Nongovernmental Organizations." Voluntas 15 (5), pp. 355-381.

Guet, I. H. (2002), Monitoring Fundraising, A Comparative Survey of ICFO Members and Their Countries. Berlin : ICFO.

Heal, G. (1976), "Do Bad Products Drive Out Good?." Quarterly Journal of Economics, 90, pp. 499-503.

Klein, B., Leffler, K. (1981), "The Role of Market Forces in Assuring Contractual Performace." Journal of Political Economy, 89, pp. 615-641.

Light, P. (2004), Sustaining Nonprofit Performance. The Case for Capacity Building and the Evidence to Support It. Brookings Institution Press, 2004.

Light, P. (2004a), "Fact Sheet on the Continued Crisis in Charitable Contributions." Available at www.brook.edu/views/papers/light/20040913.htm).

Lizzeri, A. (1999), "Information Revelation and Certification Intermediaries." RAND Journal of Economics, 30 (2), pp. 214-231.

Maryland Association of Nonprofit Organizations (2004), "Standards for Excellence (Application Package and Checklist)." www.marylandnonprofits.org. 
Muris, T. (2002), "The Interface of Competition and Consumer Protection." Prepared Remarks for the Fordham Corporate Law Institute's Twenty-Ninth Annual Conference on International Antitrust Law and Policy, New York City, October 31.

Nunez, J. (2001), "A Model of Self-Regulation." Economics Letters 74, pp. 91-97.

Nunez, J. (2002), "Corruption, Impunity, and Cover-Up in Self-Regulation." manuscript.

Ortmann, A. (1999), "The Nature and Causes of Corporate Negligence, Sham Lectures, and Ecclesiastical Indolence: Adam Smith on Joint-Stock Companies, Teachers, and Preachers." History of Political Economy, 31 (2), pp. 297 - 315.

Ortmann, A. (2001), "Capital Romance: Why Wall Street Fell in Love With Higher Education." Education Economics, 9 (3), pp. 293-311.

Ortmann, A., Schlesinger, M. (2003), "Trust, Repute, and the Role of the Nonprofit Enterprise." In Anheier, H., Ben-Ner, A., eds., The Study of the Nonprofit Enterprise. Kluwer Academic/Plenum Publishers, pp. 77-114.

Ortmann, A., Squire, R. (2000), "A Game-Theoretic Explanation of the Administrative Lattice in Institutions of Higher Learning. "Journal of Economic Behavior and Organization, 43, pp. 377-391.

Panel on the Nonprofit Sector (2005), "Interim Report." Available at http://www.nonprofitpanel.org/ interim/.

Roland, G., Verdier, T. (2003), "Law Enforcement in Transition." European Economic Review, 47 (4), pp. 669-685.

Senate Finance Committee Staff (2004), "Staff Discussion Draft (White Paper)". Available at www.finance.senate.gov/hearings/testimony/2004test/062204stfdis.pdf.

Sperling, J., Tucker, R.W. (2005/1997), For-Profit Higher Education. Developing a World-Class Workforce. New Brunswick: Transaction Publishers.

Stamler, B. (2004a), "A Round-Table Discussion on Regulating Charities." New York Times, November 14, 2004.

Stamler, B. (2004b), "After a Spate of Scandals, a Debate on New Rules." New York Times, November 15, 2004.

Stoker, B. (1897), Dracula. Available at www.classic-literature.co.uk/bram-stoker/dracula/.

Strausz, R. (2005), "Honest Certification and the Threat of Capture". International Journal of Industrial Organization, 23, pp. 45-62.

Svítková, K., Ortmann, A. (2005), "Certification as a Viable Quality Assurance Mechanism: Theory and Suggestive Evidence." CERGE-EI Working Paper No. 288.

Terlaak, A., King, A.A. (2006), "The Effect of Certification with the ISO 9000 Quality Management Standard: A Signaling Approach." Journal of Economic Behavior and Organization, 60, pp. 579-602.

Tullock, G. (1985), "Adam Smith and the Prisoners' Dilemma." The Quarterly Journal of Economics, 100 (5), pp. 1073-1081.

Wilke, B. (2003), "Monitoring Charitable Organizations: Criteria and Assessment Methods." www.icfo.de.

Wilke, B. (2005), "Transparenz im Spendenwesen: Siegel, Selbstregulierung, Watchdogs. Ein Vergleich USA, Grossbritannien und Deutschland." In Walz, W.R., Koetz, H., Rawert, P., Schmidt, K. (eds), Non Profit Law Yearbook 2004, Carl Heymans Verlag, pp. 181-206.

Wyatt, M. (2004), "The Emerging Context for NGO Governance." Trzeci Sektor, Institute of Public Affairs, Poland, November 2004. 